\title{
NOTAS SOBRE TEORIA TRÍPLICE DA AUTONOMIA, PATERNALISMO E DIREITO DE NÃO SABER NA LEGALIDADE CONSTITUCIONAL
}

Thamis Dalsenter Viveiros de Castro*

\begin{abstract}
Sumário: Introdução - 1. As novas dimensões da privacidade - 2. Dignidade da pessoa humana e paternalismo jurídico - 3. Teoria tríplice da autonomia existencial e limites ao direito de não saber - Considerações finais - Referências.
\end{abstract}

\section{INTRODUÇÃO}

Em abril de 2011, a comunidade jurídica brasileira recebeu com grande entusiasmo a notícia de que o direito de não saber, como uma das dimensões do direito à privacidade, havia chegado ao Superior Tribunal de Justiça através de demanda indenizatória que envolvia a realização não consentida de exame anti-HIV, com posterior divulgação de seu resultado para o próprio paciente. No Recurso Especial n. 1.195.995, a Terceira Turma teve a oportunidade de analisar se divulgação de dados médicos verdadeiros não solicitados pelo próprio paciente viola o direito à intimidade e à privacidade e, como consequência, enseja a compensação por danos morais.

O julgamento do REsp 1.195.995/2011 foi decorrente de ação ajuizada por Fernando Villas Boas em face do Hospital Albert Einstein, tendo em vista a realização de exame de sangue não requisitado pelo paciente e a posterior divulgação do

\footnotetext{
Doutora em Direito Civil pela Universidade do Estado do Rio de Janeiro - UERJ. Mestre em Direito Constitucional pela PUC-Rio. Professora de Direito Civil da PUC-Rio.
} 
resultado da coleta indesejada sem a sua solicitação. Em síntese, o paciente se dirigiu ao laboratório de análises clínicas com pedido médico no qual constava a solicitação de exames de sangue, dentre os quais o exame anti-HCV, pelo que se pretendia verificar a existência do vírus da Hepatite C. Ao receber o resultado da análise laboratorial, o paciente foi informado de que o sangue coletado foi testado para o exame anti-HIV, cujo resultado lhe conferia a condição de soropositivo. O resultado do exame não requisitado pelo paciente ou pelo médico solicitante das análises laboratoriais foi divulgado apenas para o próprio paciente. Diante dessa informação, que apesar de verdadeira não foi solicitada, o paciente ingressou com ação indenizatória para obter a compensação pelos danos morais sofridos em razão da violação de seu direito à intimidade e à privacidade, mais especificamente por afronta ao seu direito de não saber algo sobre si mesmo, ainda que tal informação revele dado importante sobre sua condição de saúde.

Por maioria, o Superior Tribunal de Justiça julgou improcedente a pretensão de dano moral do consumidor, tendo em vista que o resultado do exame só foi divulgado para o próprio paciente e que a divulgação dos dados permitiu que o recorrente pudesse adotar medidas mais adequadas para a preservação de sua saúde e de sua vida, considerando a potencial gravidade que o quadro de soropositividade pode acarretar. Todavia, não foi pelo entendimento majoritário que esse julgamento se tornou emblemático. Com efeito, as atenções que se voltaram para o julgamento do Recurso Especial foram atraídas pelo voto vencido, de autoria da Min. Nancy Andrighi. Em sua manifestação, a Ministra entendeu que houve lesão à privacidade do consumidor, ainda que a informação não tenha chegado ao conhecimento de terceiros, considerando que "o direito à intimidade do recorrente foi violado quando da realização de exame não autorizado, o que causou indevida invasão na esfera privada do recorrente (investigação abusiva da vida alheia). É irrelevante, portanto, o fato de que o resultado do exame não foi divulgado a terceiros. Por mais que se possa adotar a presunção de que a constatação da doença pelo recorrido lhe propiciou melhores condições de tratamento, esse fato, por si só, não retira a ilicitude de sua conduta - negligente - de realizar exame não autorizado nem pedido em favor do recorrente. Acrescente-se que a intimidade abrange o livre arbítrio das pessoas em querer saber ou não algo afeto unicamente à sua esfera privada. Vale dizer: todos têm direito de esconder suas fraquezas, sobretudo quando não estão preparadas para encarar a realidade"'.

Ementa da decisão: "I - O direito à intimidade, não é absoluto, aliás, como todo e qualquer direito individual. Na verdade, é de se admitir, excepcionalmente, a tangibilidade ao direito à intimidade, em hipóteses em que esta se revele necessária à preservação de um direito maior, seja sob o prisma individual, seja sob o enfoque do interesse público. Tal exame, é certo, não prescinde, 
De fato, o conteúdo do voto vencido revela uma das principais razóes para que a privacidade se encontre no cerne dos grandes dilemas jurídicos existenciais, que é a irremediável ligação entre privacidade e liberdade. Nesse sentido, a tutela da privacidade está em franca expansão, demandando um sistema de proteção da esfera privada como espaço efetivo de liberdade, destinado ao livre desenvolvimento pessoal nos moldes da dignidade da pessoa humana e de seus desdobramentos, representando muito mais do que o clássico right to be alone. ${ }^{2}$

em hipótese alguma, da adoção do princípio da dignidade da pessoa humana, como princípio basilar e norteador do Estado Democrático de Direito, e da razoabilidade, como critério axiológico; II - Sob o prisma individual, o direito de o indivíduo não saber que é portador do vírus HIV (caso se entenda que este seja um direito seu, decorrente da sua intimidade), sucumbe, é suplantado por um direito maior, qual seja, o direito à vida, o direito à vida com mais saúde, o direito à vida mais longeva e saudável; III - Mesmo que o indivíduo não tenha interesse ou não queira ter conhecimento sobre a enfermidade que lhe acomete (seja qual for a razão), a informação correta e sigilosa sobre seu estado de saúde dada pelo Hospital ou Laboratório, ainda que de forma involuntária, tal como ocorrera na hipótese dos autos, não tem o condão de afrontar sua intimidade, na medida em que lhe proporciona a proteção a um direito maior; IV - Não se afigura permitido, tampouco razoável que o indivíduo, com o desiderato inequívoco de resguardar sua saúde, após recorrer ao seu médico, que lhe determinou a realização de uma série de exames, vir à juízo aduzir justamente que tinha o direito de não saber que é portador de determinada doença, ainda que o conhecimento desta tenha se dado de forma involuntária. Tal proceder aproxima-se, em muito, da defesa em juízo da própria torpeza, não merecendo, por isso, guarida do Poder Judiciário; V - No caso dos autos, o exame efetuado pelo Hospital não contém equívoco, o que permite concluir que o abalo psíquico suportado pelo ora recorrente não decorre da conduta do Hospital, mas sim do fato de o recorrente ser portador do vírus HIV, no que o Hospital-recorrido, é certo, não possui qualquer responsabilidade; VI - Sob o enfoque do interesse público, assinala-se que a opção de o paciente se submeter ou não a um tratamento de combate ao vírus HIV, que, ressalte-se, somente se tornou possível e, certamente, mais eficaz graças ao conhecimento da doença, dado por ato involuntário do Hospital, é de seu exclusivo arbítrio. Entretanto, o comportamento destinado a omitir-se sobre o conhecimento da doença, que, em última análise, gera condutas igualmente omissivas quanto à prevenção e disseminação do vírus HIV, vai de encontro aos anseios sociais; VII - Num momento em que o Poder Público, por meio de exaustivas campanhas de saúde, incentiva a feitura do exame anti HIV como uma das principais formas de prevenção e controle da disseminação do vírus HIV, tem-se que o comando emanado desta augusta Corte, de repercussão e abrangência nacional, no sentido de que o cidadão teria o direito subjetivo de não saber que é soropositivo, configuraria indevida sobreposição de um direito individual (que, em si não se sustenta, tal como demonstrado) sobre o interesse público, o que, data máxima vênia, não se afigura escorreito; VII - Recurso Especial improvido. (STJ - REsp: 1195995 SP 2010/0098186-7, Relator: Ministra NANCY ANDRIGHI, Data de Julgamento: 22/03/2011, T3 - TERCEIRA TURMA, Data de Publicação: DJe 06/04/2011).

2 O "direito a estar só ou direito a ser deixado só" aparece como centro da definição da privacy consagrada por WARREN e BRANDEIS em 1890 e amplamente difundida a ponto de ser adotada expressamente pela Suprema Corte Americana. WARREN, Samuel; BRANDEIS, Louis. The right to privacy. Harvard Law Review. Cambridge: The Harvard Law Review Association, vol. IV, dez. 1890, n. 5. 
Nesse contexto, o direito de não saber, como um das dimensões do direito à privacidade, assume papel de destaque entre os civilistas dedicados ao estudo das demandas existenciais nas relaçóes privada, de modo que o presente artigo tem como objetivo analisar os desafios, o conteúdo e o limite da tutela do direito de não saber considerando a permanente tensão entre autonomia existencial e o paternalismo das intervençôes jurídicas que se dirigem à esfera privada.

\section{AS NOVAS DIMENSÕES DA PRIVACIDADE}

O desenvolvimento teórico de instrumentos de tutela da pessoa nas relaçóes privadas se intensificou especialmente nas últimas décadas, quando a agenda do direito civil assumiu como prioritária a tarefa de repensar seus institutos tradicionais de modo a adequá-los ao comando constitucional de 1988, que tem na dignidade da pessoa humana um de seus fundamentos da República. Nesse contexto, direito à privacidade assume protagonismo e ganha novas dimensões, tornando-se um elemento fundamental para tutelar as liberdades existenciais na medida da pessoa humana, especialmente porque é necessário que a noção de esfera privada compreenda espaços que são destinados, a priori, apenas às decisões individuais, verdadeiros espaços definidos por Stefano Rodotà como indecidibili per il legislatore. ${ }^{3}$

Como definir o conteúdo da tutela da privacidade na sociedade contemporânea? Diante do vertiginoso aumento do fluxo de informaçôes, torna-se ainda mais complexo determinar a correta dimensão da privacidade no mundo atual. Desde a multiplicidade de novas formas de coleta de dados até o crescente movimento de penetração dos espaços privados pelo interesse público, não há outra forma de reconhecer a privacidade senão de maneira dinâmica. Isso porque, à medida que a noção técnica de esfera privada foi ampliada, restou inevitável que o tradicional conceito de privacidade se tornasse obsoleto.

Mesmo diante das indefinições que são peculiares ao tema, pode-se compreender a esfera privada como "conjunto de ações, comportamentos, opiniōes, preferências, informações pessoais, sobre os quais o interessado pretende manter o controle exclusivo." ${ }^{\prime \prime}$ Consequentemente, afirma Rodotà, é possível tomar a privacidade como segundo "o direito de manter o controle sobre suas próprias

3 Rodotà, Stefano. Politici, liberateci dalla vostra coscienza. Disponível em: <http://daleggere. wordpress.com/2008/01/13/stefano-rodota-\%C2\%ABpolitici-liberateci-dalla-vostra-coscienza\%C2\%BB/> Acesso em: 19 set. 2017.

4 Rodotà, Stefano. A vida na sociedade de vigilância: a privacidade hoje. A vida na sociedade de vigilância. Rio de Janeiro: Renovar, 2008. 
informaçôes." Es Essa forma dinâmica de compreender a privacidade, aliás, é o único modo capaz de tutelar a integralidade da pessoa, haja vista que não se podem clausular em conceitos ou previsóes normativas todos os aspectos pessoais que devam ser tutelados.

Como consequência desse raciocínio, torna-se evidente que a privacidade não possui apenas um viés negativo. Trata-se, efetivamente, de direito talhado para o exercício da função promocional que lhe é contemporaneamente atribuída, vale dizer, dentre as funções que a privacidade acumulou ao longo das últimas décadas merece destaque a sua vocação para, a despeito de lesão ou ameaça, assegurar os espaços próprios à construção da esfera pessoal livre de ingerências privadas ou públicas. Desse modo, a privacidade relaciona-se à esfera íntima da pessoa de diversas formas, desdobrando-se na individualidade, na liberdade, na autorrepresentação de si, na liberdade de conformação pessoal, representando muito mais do que o clássico "direito a estar só". ${ }^{6}$ No que se refere à proteção da esfera privada como espaço efetivo de liberdade destinado à realização das subjetividades, deve-se compreender que o direito à privacidade constitui elo fundamental para a garantia de proteção dos mais caros valores de um Estado Democrático de Direito.

A proteção da privacidade e de seus corolários no ordenamento jurídico brasileiro é expressamente prevista na Constituição Federal de 1988, em seu 5º X7 , e no último artigo do rol de direitos da personalidade do Código Civil de 2002, o art. $21^{8}$. Diante de sua função promocional, a interpretação desses instrumentos legais de tutela privacidade deve ser sempre ampliada no sentido de alcançar as novas demandas que se apresentam desde que os aspectos mais íntimos da personalidade ultrapassaram as fronteiras do corpo e passaram a circular amplamente nos espaços sociais, sejam eles reais ou virtuais.

De fato, a tutela da privacidade, que sofreu profundas e contínuas alteraçóes desde que abandonou a sua tradicional roupagem de "direito dos egoísmos privado"", encontrou novos e importantes desafios decorrentes das novas formas

Ibid.

6 DONEDA, Danilo. Da privacidade à proteção de dados pessoais. Rio de Janeiro: Renovar, 2006, p. 23.

7 Artigo 5 $, \mathrm{X}, \mathrm{CF}$ - são invioláveis a intimidade, a vida privada, a honra e a imagem das pessoas, assegurado o direito a indenização pelo dano material ou moral decorrente de sua violação.

8 Art. 21, CC - A vida privada da pessoa natural é inviolável, e o juiz, a requerimento do interessado, adotará as providências necessárias para impedir ou fazer cessar ato contrário a esta norma.

9 DONEDA, Danilo. Da privacidade à proteção de dados pessoais. Rio de Janeiro: Renovar, 2006, p. 23. 
de circulação de dados pessoais, em especial os denominados dados sensíveis. São denominados dados sensíveis aqueles de natureza existencial, que dizem respeito à essência da personalidade de uma pessoa. Essa espécie de dado demanda tutela reforçada, carecendo de maior rigor no controle da coleta e da circulação, tendo em vista que se referem a informações relacionadas a aspectos íntimos da pessoa humana, como são os dados que refletem aspectos de saúde, convicção política, religião e temas conexos. ${ }^{10} \mathrm{Se}$ os dados de natureza patrimonial, como aqueles que dizem respeito ao sigilo bancário e fiscal, recebem adequada proteção por parte dos tribunais brasileiros, o mesmo não se pode dizer sobre a proteção que se reserva para dados de natureza sensível, havendo um longo caminho a percorrer para que o Brasil se aproxime de experiências estrangeiras bem sucedidas no cuidado e manipulação de informações sensíveis ${ }^{11}$.

Especialmente nesse contexto, em que os dados que circulam revelam a essência da personalidade, a privacidade se expande e alcança a noção de autodeterminação informativa, que garante a ingerência da pessoa sobre todas as etapas de circulação do dado pessoal, desde a coleta até o armazenamento e o descarte desses dados. Isso significa, por seu turno, a necessidade de controlar as informações para delimitar quais serão os dados de acesso livre, quais serão os dados de acesso social restrito e quais serão os dados que não poderão ser acessados, seja pela natureza da informação ou pelo tempo em que foi produzida. Há ainda que se investigar a presença de dados sobre os quais nem mesmo o próprio titular deve ter acesso caso não haja consentido com a sua coleta. Todas essas situações podem ser traduzidas nos recentes direito ao esquecimento - ou melhor, o direito de controlar as informações pessoais pretéritas, e direito de não saber algo sobre si mesmo ${ }^{12}$.

A criação dessas novas categorias jurídicas referentes ao controle de informações ampliou e tornou ainda mais dramática a tarefa de delimitar o conteúdo do direito à privacidade. Sobre a autonomia desses novos institutos, parece acertado afirmar que tanto o direito de não saber algo sobre si mesmo quanto o direito de

10 SCHREIBER, Anderson. Direitos da personalidade. São Paulo: Atlas, 2011, p. 153-154.

11 SCHREIBER, Anderson. Direitos da personalidade. São Paulo: Atlas, 2011, p. 153-154.

12 Como descreve Caitlin Mulholland sobre a expansão da privacidade, as suas dimensões podem ser sintetizadas em (i) o direito de ser deixado só, (ii) o direito de ter controle sobre a circulação dos dados pessoais, e (iii) o direito à liberdade das escolhas pessoais de caráter existencial, soma-se um novo entendimento, o de que a pessoa titular de determinado dado relacionado a sua condição existencial tem o direito de não conhecê-lo. MULHOLLAND, Caitlin. O direito de não saber como decorrência do direito à intimidade. Civilistica.com, N. 1, 2012. Disponível em: <http://civilistica.com/wp-content/uploads/2012/09/Direito-de-nao-saber-civilistica.com-1.-2012.pdf>. 
realizar o controle de informações pessoais pretéritas configuram desdobramentos do direito à privacidade, e não propriamente novos direitos dotados de autonomia no ordenamento brasileiro. A esse respeito é preciso que se diga, ainda, que o caráter derivado desses direitos não se deve à ausência de previsão legislativa expressa, dado que não se credita ao Código Civil esgotar as hipóteses de atributos tuteláveis em seus parcos onze artigos destinados à proteção da pessoa em seus aspectos existenciais. De fato, o rol dos direitos da personalidade, cuja prescrição se encontra nos artigos 11 a 21, é meramente exemplificativo, especialmente porque "não existe um número fechado de hipóteses tuteladas: tutelado é o valor da pessoa sem limites, salvo aqueles colocados nos seus interesses e naqueles de outras pessoas". ${ }^{13}$ Cuida-se, com efeito, de considerá-los como novas dimensóes do direito à privacidade $^{14}$, vez que partilham a mesma ratio e decorrem de atualizaçôes hermenêuticas que aproximam a tutela da privacidade prevista pelo constituinte de 1988 e pelo legislador de 2002 das transformações sofridas pela sociedade atual.

$\mathrm{O}$ reconhecimento judicial desses novos instrumentos de tutela de informações não é isento de polêmicas. No caso Aída Curi, ${ }^{15}$ seus irmãos Nelson Curi, Roberto Curi, Waldir Cury e Maurício Curi ajuizaram ação objetivando reparação de danos materiais e morais decorrentes de ato praticado pela TV Globo Ltda. por ocasião da veiculação do programa televisivo Linha Direta retratando os episódios relativos à morte de Aída Curi, vítima de terrível homicídio em 1958. Enquanto para o pedido de dano moral o fundamento foi a reviver dores e feridas do passado, para o dano material o argumento foi de utilização da imagem para fim comercial ou lucrativo. O STJ não reconheceu o direito à indenização, e o acórdão do Ministro Relator Luis Felipe Salomão assentou que, naquela situação, os fatos eram verídicos e revelavam notícia histórica de repercussão nacional, conferindo, no caso concreto, maior peso à liberdade de imprensa e não à proteção da privacidade e da inviolabilidade da privada e de seus desdobramentos sobre a imagem e a honra.

13 PERLINGIERI, Perlingieri. O direito civil na legalidade constitucional, Rio de Janeiro: Renovar, 2008, p. 764.

14 Cf. VIVEIROS DE CASTRO, Thamis, ALMEIDA, Vitor. O direito ao esquecimento da pessoa transexual. In: TEPEDINO, Gustavo; TEIXEIRA, Ana Carolina Brochado; ALMEIDA, Vitor (Coord.). Da dogmática à efetividade do direito civil: Anais do Congresso Internacional de Direito Civil Constitucional - IV Congresso do IBDCIVIL. Belo Horizonte: Fórum, 2017.

15 BUCAR, Daniel. Controle temporal de dados: o direito ao esquecimento. civilistica.com. Disponível em: http://civilistica.com/wp-content/uploads/2013/10/Direito-ao-esquecimento-civilistica.com-a.2.n. 3.2012.pdf. Acesso em: 08/02/2018. 
No caso que ficou conhecido como Chacina da Candelária, o autor da demanda, JGM, ingressou com ação indenizatória em face da TV Globo Ltda., pleiteando o reconhecimento de que a notícia de seu indiciamento como coautor dos crimes, feita pelo programa televisivo Linha Direta Justiça treze anos após o evento original, acarretou a violação de seu direito ao esquecimento. $\mathrm{O}$ autor alegou que, ainda que tenha havido expressa informação de sua absolvição, a veiculação do programa em rede nacional gerou intenso abalo emocional. No Superior Tribunal de Justiça, reconheceu-se o pleito indenizatório, conferindo maior peso à privacidade e ao direito ao esquecimento na ponderação com a liberdade de expressão, tendo como base o fato de que as informações, apesar de verídicas, não eram contemporâneas e sua veiculação tanto tempo após o evento causavam variados transtornos ao autor da demanda, assentando o direito ao esquecimento como um "direito à esperança em absoluta sintonia com a presunção legal de regenerabilidade da pessoa humana."16

Os dois casos brevemente relatados se tornaram referência no debate sobre o direito ao esquecimento, e servem para ilustrar como se dá a contraposição mais frequente à tutela da privacidade sob esta perspectiva, através da liberdade de expressão. Trata-se de situações que envolvem a necessidade real de ponderação, vez envolvem interesses que se ligam de forma legítima aos pilares de uma democracia pluralista. Todavia, essa não é a mesma tônica que acompanha o debate sobre o direito de não saber, como se verá a seguir.

Um retorno ao emblemático e já mencionado REsp 1.195.995/2011 ajudará na reflexão proposta. $\mathrm{O}$ Recurso Especial teve origem na ação ajuizada por Fernando Villas Boas em face do Hospital Albert Einstein, tendo em vista a realização de exame de sangue não requisitado pelo paciente e a posterior divulgação do resultado da coleta indesejada sem a sua solicitação. A decisão recorrida julgou improcedente o pleito indenizatório com base nos seguintes argumentos: o dado comunicado era verdadeiro; o resultado do exame não foi divulgado a terceiros; a informação sobre a condição de saúde trouxe benefícios ao paciente e, por fim, como a doença não foi contraída no hospital restou afastado o nexo causal entre a conduta e o dano ${ }^{17}$.

\footnotetext{
STJ. REsp n. 1.334.097/RJ, Rel. Min. Felipe Salomão, julg. 28/5/2013.

17 Ementa da decisão mencionada: APELAÇÃO - RESPONSABILIDADE CIVIL - INDENIZAÇÃO - DANOS MATERIAIS E MORAIS - Demanda ajuizada em face de laboratório de análises clínicas - Exame realizado para pesquisa de anticorpos (HIV) - Resultado positivo - Solicitação médica de exame de sangue anti HCV - Embora objetiva a responsabilidade do laboratório, não há como reconhecer sua culpa, pela ausência de nexo causal -
} 
Por maioria, a Terceira Turma do STJ também julgou improcedente o pleito indenizatório do consumidor e determinou que a conduta do laboratório não afrontou o direito à intimidade do autor. $\mathrm{O}$ voto do Ministro Massami Uyeda, que foi acompanhado pelos Ministros Sidnei Beneti, Paulo de Tarso Sanseverino e Vasco Della Giustina, desembargador convocado do TJ/RS, considerou que caráter não absoluto do direito à intimidade admite a prevalência de outros interesses, sejam eles públicos ou privados. Para os Ministros, a proteção da privacidade perde força, no caso concreto, diante da necessidade de tutelar um direito maior, que seria o direito à vida, "uma vida saudável e longeva", correspondente, aos olhos dos julgadores, à noção de melhor interesse do autor da demanda. Ao lado desse argumento, os julgadores também assentaram a preocupação de ordem social, de modo que ficou registrado que "todo direito deve ser exercido com responsabilidade, dentro de um contexto social, sob pena de se verificar o abuso de tal direito", enfatizando a ponderação do direito à intimidade com a tutela da saúde pública, especialmente num momento em que, de acordo com trecho do voto do Relator: "o Poder Público, por meio de exaustivas campanhas de saúde, incentiva a feitura do exame anti-HIV como uma das principais formas de prevenção e controle da disseminação do vírus HIV, tem-se que o comando emanado dessa a.Corte, de repercussão e abrangência nacional, no sentido de que o cidadão teria o direito subjetivo de não saber que é soropositivo, configuraria sobreposição de um direito individual (que, em si, não se sustenta como demonstrado) sobre o interesse público, o que, data maxima venia, não se afigura escorreito."

Os argumentos apresentados pelo julgador podem ser agrupados em dois grandes eixos. De um lado tem-se o argumento de interesse público, segundo o qual a saúde pública estaria em risco diante da ignorância sobre dado de saúde que revela a soropositividade, e do outro lado tem-se o argumento de ordem privada, que se refere à imposição judicial de modos de viver, considerando que o conhecimento sobre o resultado positivo do exame de HIV é fundamental para salvaguardar o direito à vida melhor, com mais saúde e mais longeva. As duas linhas de raciocínio prescrevem ingerências na esfera privada, ainda que partilhem de premissas diversas. Isso significa, por seu turno, que a decisão promove uma profunda intervenção no campo de autonomia pessoal, de tal modo que se questiona a legitimidade da posição paternalista adotada pela Corte. É necessário, portanto, verificar como se dá a proteção da autonomia existencial e da privacidade nesse contexto.

Inexistência de comunicação de falsa doença - De rigor a improcedência da ação - Sentença mantida - Recurso desprovido. 


\section{DIGNIDADE DA PESSOA HUMANA E PATERNALISMO JURÍDICO}

De acordo com a metodologia civil-constitucional, a análise da legitimida$\mathrm{de}^{18}$ das intervençóes estatais sobre a autonomia existencial deve considerar que a positivação da dignidade da pessoa humana na Constituição Federal de 1988 como um dos fundamentos da República (art. $1^{\text {o }}$, III ${ }^{19}$ ) revela a opção constituinte pela função promocional do direito ${ }^{20}$. Dessa premissa decorre a preeminência das situaçôes existenciais sobre as patrimoniais e a consequente transformação do conceito tradicional de autonomia, que deverá ser compreendido para além da liberdade formal de declarar a vontade patrimonial2 ${ }^{21}$. Como decorrência direta deste raciocínio, o sujeito de direito - abstratamente considerado de acordo com a lógica tradicional segundo a qual era importante definir e tutelar as pessoas como sujeitos que detêm coisas sobre as quais lhe são asseguradas toda sorte de prerrogativas proprietárias - perdeu espaço para a pessoa concretamente identificada no seio das relações jurídicas, nas quais será tutelada em virtude do valor dignidade e não apenas de suas potencialidades patrimoniais

Neste contexto, a dignidade configura-se como cláusula geral de tutela e promoção da personalidade, ${ }^{22}$ geradora de deveres positivos e negativos, a qual pressupõe que a pessoa seja concebida a partir de uma reflexão multidisciplinar. Isto é, a dignidade, no papel de princípio unificador do ordenamento jurídico, impóe que o olhar dirigido à pessoa seja capaz de englobar a integralidade do indivíduo, levando-se em conta o contexto social, econômico e cultural e as necessidades físicas e psíquicas de cada sujeito.

Desta forma, o princípio da dignidade da pessoa humana impõe o compromisso de tutela promocional da pessoa de acordo com uma perspectiva emancipatória,

18 PERLINGIERI, Pietro. A doutrina do direito civil na legalidade constitucional. In: TEPEDINO, Gustavo (org.). Direito civil contemporâneo: novos problemas à luz da legalidade constitucional. São Paulo: Atlas, 2008, p. 263.

19 Art. 10 A República Federativa do Brasil, formada pela união indissolúvel dos Estados e Municípios e do Distrito Federal, constitui-se em Estado Democrático de Direito e tem como fundamentos: I - a soberania; II - a cidadania; III - a dignidade da pessoa humana; IV - os valores sociais do trabalho e da livre iniciativa; $\mathrm{V}$ - o pluralismo político.

20 Para uma análise detalhada dessa transição funcional no direito, v. por todos: BOBBIO, Norberto. Da estrutura à função. Trad. Daniela Beccaccia Versiani. Barueri: Manole, 2007.

21 SARMENTO, Daniel. Direitos fundamentais e relaçôes privadas. Rio de Janeiro: Renovar, 2008, p. 26.

22 TEPEDINO, Gustavo. A tutela da personalidade no ordenamento civil-constitucional brasileiro, in Temas de Direito Civil, Rio de Janeiro: Renovar, 2004, p. 23-58. 
segundo a qual a liberdade é pressuposto inafastável do projeto de desenvolvimento da personalidade. ${ }^{23}$ Assim, as intervençôes feitas na autonomia privada devem ser analisadas criticamente, a fim de refutar a lógica de um Estado excessivamente paternalista que pretende tomar decisões por seus filhos - sempre incapazes de reconhecer o que é o melhor - em busca de um Estado que reconheça a liberdade e autonomia de seus representados, tendo como objetivo inafastável a realização dos diversos planos de vida que certamente surgirão.

De acordo com essa perspectiva de pluralismo democrático, Günther Frankenberg alerta sobre a expansão do Estado paternalista nos tribunais: se há uma nova tendência, então é a da persistência dos juízes em uma violação da dignidade, mesmo contra a vontade do envolvido. ${ }^{24}$ Ora, ainda que se trate de opinião formulada com base na realidade jurídica alemã, não se pode ignorar que o movimento estatal de intervenções paternalistas é cada dia mais intenso também no cenário brasileiro, ${ }^{25}$ como se pode perceber no caso do direito de não saber, de modo que noção de paternalismo possui enorme relevância prática para o direito, em especial para a esfera cível, na qual é possível verificar com mais clareza o problema da legitimidade das limitações à liberdade existencial na esfera das relaçóes privadas - executadas principalmente por parte do Poder Legislativo na elaboração de leis e pelo Poder Judiciário na aplicação concreta de preceitos legais.

Qualquer instância ou pessoa que tenha como responsabilidade a promoção do bem-estar de alguém específico, ou da sociedade em geral, frequentemente terá que enfrentar dilemas decorrentes da situação bastante comum que ocorre quando o próprio sujeito a quem se dirige esta incumbência resiste à tutela externa dos seus desejos e convicções. Isso pode acontecer em qualquer aspecto da vida ${ }^{26}$. As

23 SARMENTO, Daniel. Direitos fundamentais e relaçôes privadas. Rio de Janeiro: Lumen Juris, 2008, p. 26.

24 FRANKENBERG, Günther A gramática da Constituição e do direito. Trad. Elisete Antoniuk. Belo Horizonte: Del Rey, 2007, p. 317.

25 Muitas dessas intervençōes são reverenciadas como verdadeira expressão da força civilizatória do direito, como é o caso da Lei Maria da Penha, enquanto outras são questionáveis por representarem, em alguma medida e muitas vezes justificadamente, limitação severa na autonomia privada, como é o caso da proibição de fumar em lugares fechados.

26 Nesse sentido, veja a definição apresentada pelo verbete sobre o termo paternalismo no Dicionário de Política: "Na linguagem vulgar, Paternalismo indica uma política social orientada ao bem-estar dos cidadãos e do povo, mas que exclui a sua direta participação: é uma política autoritária e benévola, uma atividade assistencial em favor do povo, exercida desde o alto, com métodos meramente administrativos. Para expressar tal política, nos referimos, então, usando de uma analogia, à atividade benevolente do pai para com seus filhos menores." BOBBIO, Norberto; MATEUCCI, Nicola; PASQUINO, Gianfranco. Dicionário de Política. v. II, Brasília: Editora UnB, 2010, p. 908 e ss. 
relações entre pais e filhos, professores e alunos, médicos e pacientes, sempre têm espaço para este tipo de conflito entre vontades divergentes sobre o bem-estar de um sujeito. A relação entre o Estado e as pessoas por ele contempladas é o campo mais problemático quando o tema é paternalismo, já que não é simples conjugar os interesses coletivos e os interesses individuais numa relação de harmonia quando o assunto é proteger a pessoa contra ela mesma.

Torna-se clara, portanto, a importância de se compreender quais intervençōes jurídicas podem ser consideradas legítimas e quais serão ilegítimas de acordo com a legalidade constitucional. Essa análise sobre a legitimidade passa, necessariamente, por considerações acerca do caráter paternalista e do grau de paternalismo que uma restrição à autonomia pode apresentar. Para isso é preciso salientar que nem toda intervenção paternalista será, por si, intolerável de acordo com a Constituição Federal, mesmo sendo necessário afastar toda sorte de intervenções que esvaziem de sentido o projeto de livre desenvolvimento da personalidade.

Mas o que exatamente pode ser considerado paternalismo jurídico? Qualquer limitação jurídica imposta à liberdade de um sujeito pode ser considerada paternalista e isso é algo irremediavelmente negativo ou há espaços para algum grau tolerável de paternalismo? Quais fatores devem ser considerados para averiguar uma possível tolerância a limites externos impostos à liberdade de existir?

Ainda que as origens do conceito sejam muito mais antigas, ${ }^{27}$ Macario Alemany explica, em livro dedicado ao estudo do tema, que o emprego do termo paternalismo se tornou particularmente comum no contexto da segunda metade do século XIX e nas primeiras décadas do século XX, quando foi usado para descrever um certo modelo de condutas que expressavam o paternalismo do tipo industrial. Essa categoria de paternalismo era verificado em determinadas práticas sociais típicas das relações de trabalho, principalmente no ambiente das fábricas. ${ }^{28}$ No âmbito jusfilosófico, no entanto, a questão do paternalismo tomou fôlego a partir das análises apresentadas por Herbert L.A Hart sobre as regras de conteúdo moral, aprofundadas principalmente na famosa polêmica entre ele e Patrick Devlin.

27 Sobre as origens do paternalismo e também do pensamento antipaternalista, ver, especialmente, BOBBIO, Norberto; MATEUCCI, Nicola; PASQUINO, Gianfranco. Dicionário de politica. v. II, Brasília: Editora UNB, 2010, p. 909-910.

28 Como esclarece o autor, "prácticas sociales desarrolladas por los patronos en relación a sus trabajadores caracterizadas por la Asunción de responsabilidades en la mejora da calidade de vida del obrero, las cuales rebasavan con creces el cumprimento de las condiciones contratuales en materia de salario y condiciones de trabajo." ALEMANY, Macario. El paternalismo jurídico. Madrid: Iustel, 2006, p. 30. 
Em oposição à perspectiva denominada moralismo legal - que diz respeito ao uso da coerção legal para impedir atos imorais -, Hart protagonizou o mais emblemático debate teórico sobre paternalismo, partindo de uma série de análises críticas sobre as proposiçōes liberais defendidas por Stuart Mill em On Liberty. ${ }^{29} \mathrm{Na}$ outra ponta desta disputa estava Patrick Devlin, em defesa da tendência combatida por Hart e em nome de uma intervenção legislativa de ordem penal para criminalizar condutas consideradas imorais, cujo fundamento estaria na proteção da sociedade e não propriamente na proteção do indivíduo contra ele mesmo, segundo argumentava o autor. ${ }^{30}$

A questão jurídica que serviu como base para o embate teórico versava sobre a criminalização da prostituição e da homossexualidade. Para Devlin, toda sociedade precisaria de intervenções jurídicas para assegurar a prevalência dos valores morais sobre as imoralidades sociais, termo que utilizava para classificar todo tipo de prostituição ou desvios na moral sexual dominante. Para Devlin, os desvios podem ser caracterizados a partir do comportamento de pessoas consideradas honradas e honestas. Em posição oposta, Hart sustentou que não havia possibilidade de criminalizar condutas considerando como imoral aquilo que as pessoas adultas e capazes resolvem fazer para viver a experiência sexual.

Mas essa posição contrária ao moralismo legal não significava, para Hart, a necessária negação do paternalismo. Daí a relevância do raciocínio apresentado pelo autor: para ele, o paternalismo significa a imposição de um padrão de conduta visando ao bem de uma pessoa, enquanto o moralismo impõe limitaçôes à autonomia existencial sem que haja qualquer lesão ou ameaça de lesão ao sujeito cuja liberdade se deseja limitar. De acordo com o moralismo, a coerção legal por meio da moral se daria com vistas à proteção dos interesses da sociedade, a fim de evitar o que se chamou de forma pouco esclarecedora de degradação moral, sem preocupações acerca do bem-estar do sujeito a quem se dirige a intervenção. Enquanto no moralismo a justificação não está atrelada aos valores individuais, e muito menos aos efeitos jurídicos que o ato de autonomia pode provocar, o paternalismo jurídico, ao contrário, se liga definitivamente aos efeitos produzidos e se desdobra em diversas qualificações a depender do grau de intensidade das intervençôes restritivas e dos interesses que visam tutelar.

De acordo com Gerald Dworkin, o paternalismo seria uma "interferência na liberdade de ação do indivíduo, justificada por razões que se referem exclusivamente

29 MILL, Stuart. On Liberty. Kitchner: Batoche Books, 2001.

30 DEVLIN, Patrick. The enforcement of morals. Oxford Press University, 1959, p. 13 e ss. 
ao bem-estar, ao benefício, à felicidade, às necessidades, aos interesses ou valores da pessoa coagida"31. Como esclarece Letícia Martel, um traço marcante do paternalismo é que "no momento em que ele é aplicado, a pessoa não reconhece a proteção nem o benefício da medida." 32

Contudo essa concepção de paternalismo ${ }^{33}$ está longe de esgotar a problemática a ser enfrentada sobre o tema, já que o paternalismo é gênero do qual decorrem diversas espécies, como o paternalismo médico, o paternalismo político, o paternalismo benevolente, como expressão da relação entre pais e filhos, e, finalmente, o paternalismo jurídico. Então, como se pode definir o paternalismo jurídico?

Uma importante definição sobre paternalismo jurídico é proposta por Macario Alemany, ${ }^{34}$ segundo o qual haverá uma intervenção paternalista quando dois requisitos estiverem presentes: (i) A exerce poder sobre B; (ii) esse poder de A é exercido com o propósito de evitar que $\mathrm{B}$ pratique açôes (ou deixe de praticar) que causem danos a si mesmo ou representem um aumento de risco de dano. A partir desse raciocínio, seria possível afirmar a intervenção como decorrente do paternalismo jurídico se o exercício de poder de A sobre B for respaldado pelo direito, ou seja, se A tem poderes jurídicos para determinar, por si, modificações na situação jurídica de B (mesmo que B não queira). ${ }^{35}$

Uma vez caracterizada que a intervenção é fundada no paternalismo jurídico, a problemática se coloca em outros termos, pois as modalidades de paternalismo podem ser categorizadas de diversas maneiras. A principal distinção sobre os tipos

31 DWORKIN, Gerald. Paternalism. Monist, LVI, n. 1, junho de 1972, p. 65.

32 MARTEL, Letícia de Campos Velho. Direitos Fundamentais Indisponíveis: os limites e os padrôes do consentimento para a autolimitação do direito fundamental à vida. Tese de Doutorado. Rio de Janeiro: UERJ.

33 Sobre o desenvolvimento do conceito de paternalismo utilizado por Gerald Dworkin, Letícia Martel esclarece que "Em seu primeiro conceito, Gerald Dworkin associou o paternalismo a intervençôes coercitivas. Devido às críticas que recebeu, modificou seu posicionamento e passou a aceitar como paternalistas algumas medidas promocionais e de dificultação de acesso a comportamentos ou produtos, bem como a omissão de informações importantes que impedem o conhecimento, pelo sujeito que sofre a medida paternalista, sobre a sua ocorrência." MARTEL, Letícia de Campos Velho. Direitos fundamentais indisponiveis: os limites e os padrões do consentimento para a autolimitação do direito fundamental à vida. Tese de Doutorado. Rio de Janeiro: UERJ, p. 90. Outra importante análise crítica sobre o pensamento de Dworkin é feita por Macario ALEMANY, em seu livro El paternalismo jurídico. Madrid: Iustel, 2006.

34 Para uma importante crítica à teoria de Macario Alemany, ver o prólogo de seu próprio livro, escrito por Manuel Atienza, em: Alemany, Macario. El paternalismo jurídico, Madrid: Iustel, 2006, p. 16-22.

35 ALEMANY, Macario. El paternalismo jurídico. Madrid: Iustel, 2006. 
de intervenção paternalista se relaciona com o fim a que se destinam: ${ }^{36}$ algumas ingerências paternalistas querem afastar o sujeito despido de autonomia, temporariamente ou definitivamente, do mal que possa infringi-lo, enquanto outras têm como objetivo promover o bem quando o sujeito não possui os mecanismos para reconhecer como seu melhor interesse. ${ }^{37}$

Uma dessas modalidades, também classificada como paternalismo fraco, fundamenta as intervenções nas hipóteses em que o mal resulta da falta de escolha ou do desconhecimento sobre o potencial lesivo da conduta intentada. É exemplo dessa intervenção paternalista a ação que visa afastar a ameaça de que uma conduta involuntária resulte em situações não benéficas ao sujeito como, por exemplo, impedir uma pessoa que se sabe estar sob efeito de alucinógenos se jogue pela janela. Do mesmo modo, o agir paternalista comporta a movimentação que decorre da ignorância sobre o mal em potencial como, por exemplo, impedir alguém de ingerir substância que ignora ser tóxica ou venenosa. Abrange ainda a hipótese em que se julga necessário agir na dúvida sobre a voluntariedade ou não da situação, por exemplo, tirar uma pessoa da frente de um ônibus mesmo sem saber se ela deseja levar a vida a termo. ${ }^{38}$

A segunda modalidade, chamada de paternalismo forte, admite a intervenção sobre a conduta quando o mal resulta de uma ação voluntária e informada. O paternalismo deste tipo é tradicionalmente identificado nas políticas públicas como campanhas de combate ao fumo, leis que proíbem o fumo em lugares fechados, leis que determinam índices de consumo alcoólico compatíveis com a direção de veículos automotivos, leis que restringem o porte de armas, leis que impóem a vacinação obrigatória, políticas públicas que determinam o controle intenso de doenças. ${ }^{39}$

36 Nesse sentido, vale a transcrição da análise de Fermin Schramnm acerca do tema: "a especificidade da ética contemporânea (cujas raízes se situam no humanismo moderno) consiste em opor alguma forma de autogoverno a alguma forma de aceitação do paternalismo, numa gradação que pode ser classificada da seguinte maneira: 1) o paternalismo "duro" (hard paternalism), que implica uma restrição às liberdades ou uma violação da autonomia; 2) o paternalismo "forte" (strong paternalism), que implica, além da restrição ou da violação, o caráter de não justificado; 3) o paternalismo "brando" (soft paternalism), que não envolve nem restrições nem violaçôes mas somente meios retóricos de convencimento; 4) o paternalismo "mole" (weak paternalism), ou seja, uma forma de hard paternalism justificado". Schramm, Fermim. A autonomia difícil. Bioética, Brasília, v. 6, n. 1, p. 27-37, 1998.

37 PALMER, Michael. Problemas morais em medicina. São Paulo: Editora do Centro Universitário São Camilo, 2002, p. 158.

38 PALMER, Michael. Problemas morais em medicina. São Paulo: Editora do Centro Universitário São Camilo, 2002, p. 158.

39 Ibidem, p. 159. 
Em tais situações, tem-se uma intervenção estatal legitimada, de um lado, pela proteção da esfera jurídica de terceiros, ou seja, o Estado atua proibindo o fumo em lugares fechados para proteger o não fumante dos riscos do fumo passivo, proíbe a direção da pessoa alcoolizada para não trazer riscos de acidentes na via pública, o porte de armas pode ser restrito em face dos perigos que elas representam para a vida de outras pessoas, a vacinação obrigatória é de suma importância para que doenças contagiosas não acarretem epIdemias ou pandemias. De outro lado, esse tipo de atuação estatal visa a desestimular a prática desses atos através da conscientização da população em relação aos efeitos lesivos de tais práticas. Mas veja-se que esta consequência é buscada de modo residual, vale dizer, o fumante que não pode fumar em recintos fechados acaba fumando menos, a criança vacinada não contamina outras crianças ao mesmo tempo em que se torna imune à doença, o motorista que não pode dirigir alcoolizado não coloca a vida de outras pessoas em risco e nem a sua. De modo geral, portanto, trata-se de condutas que causam riscos à própria pessoa e à sociedade.

Frequentemente, as hipóteses que ensejam o paternalismo forte são chamadas de atos acráticos, ou seja, práticas paradoxais em relação à racionalidade. São movimentos voluntários que o sujeito opta por executar mesmo consciente dos males que podem ocorrer, a exemplo do fumante que, mesmo sabendo dos prejuízos causados pelo tabagismo, continua a fumar. Do mesmo modo, os excessos no hábito de beber e comer acarretam consequências nefastas que são consideradas pelos sujeitos, mas não afastadas, de modo que se tornam menores diante do prazer que tais práticas podem proporcionar. Não raro, a dependência recebe o crédito pela prática de atos acráticos. ${ }^{40} \mathrm{~A}$ vontade se tornaria fraca diante de fatores que fogem à racionalidade. Assim, justifica-se que o tabagista continue a fumar porque o cigarro contém substâncias que geram dependência; de maneira idêntica a obesidade mórbida é explicada em razão de desequilíbrios químicos que geram a compulsão e interditam a vontade.

De outra parte, são inúmeros os atos acráticos que não derivam de influências que causem dependência, como o fato de as Testemunhas de Jeová se recusarem a receber uma transfusão de sangue que sabem ser imprescindível à manutenção de suas vidas, ou ainda as situaçôes em que o paciente depende da amputação de um de seus membros para ter a vida salva, mas mesmo assim recusa-se a fazer a operação. Nesses casos, contudo, não se pode afirmar categoricamente que se trata de

40 Bodin de Moraes, Maria Celina. Na medida da pessoa humana: estudos de direito civil-constitucional. Rio de Janeiro: Renovar, 2010, p. 193. 
fraqueza de vontade. As Testemunhas de Jeová não se recusam a viver, mas certamente possuem padrões sobre a vida que fogem à moral tradicional: trata-se, na verdade, de uma consequência da liberdade de consciência, ${ }^{41}$ de modo que o sujeito se recusa ao cumprimento daquilo que se reputa tradicionalmente como razoável ou lícito, mas que é incompatível com as suas íntimas convicções. Neste caso específico ocorre situação em que a pessoa sente-se moralmente obrigada a não cumprir com as expectativas razoáveis por força de suas convicções de crença religiosa.

De acordo com as restrições da autonomia por razões de consciência, assinala-se que independente da liberdade de escolha e das suas íntimas convicções, o sujeito não pode fazer do exercício de sua autonomia um risco à esfera jurídica de terceiros. Assim, no exemplo apresentado sobre a recusa de tratamento médico de Testemunha de Jeová, convém assinalar que a objeção de consciência ${ }^{42}$ da mãe não é capaz de conferir o corpo do filho como campo de sua própria autonomia, de modo que o tratamento médico deverá ser implementado, sob pena de abuso de poder familiar.

Com efeito, o paternalismo perde espaço para as convicções pessoais nesses casos não só por se tratarem de hipóteses de exercício da liberdade religiosa ${ }^{43}$, mas também porque representam situaçôes de conflitos verdadeiramente existenciais. Nessas situações, a observância do dever jurídico de preservação da integridade física (como pressuposto necessário à continuidade da vida) significaria uma violação da ordem psíquica, de onde se conclui que esses espaços de liberdade, quando violados, são punidos com os aspectos subjetivos da própria personalidade.

Tendo isso em vista, como é possível assegurar que a incidência do direito nas relações privadas existenciais se dê de maneira efetivamente protetiva e não somente restritiva? Como encontrar a medida para que a tutela da pessoa no ordenamento jurídico brasileiro não se confunda com uma postura moralista por parte do legislador e nem mesmo dos intérpretes da lei? Como garantir o direito de

41 Tradicionalmente, esse tipo de liberdade de consciência recebe o nome de objeção de consciência, tema caro aos estudiosos do direito penal, como elemento de exclusão da culpabilidade. SANTOS, Juarez Cirino dos. Direito penal - parte geral. Curitiba: ICPC; Lumen Juris, 2005, p. 260.

42 De acordo com a lição de Ramón Soriano, "La objeción de conciencia es así una forma de la libertad ideológica de la persona, que consiste en la excepción justificada del cumplimento de un deber jurídico colisionante con los dictados de la conciencia individual”. SORIANO, Ramón. La desobediencia civil. Barcelona: PPU, 1991, p. 45.

43 Sobre o conceito de liberdade religiosa e a sua interpretação na Constituição brasileira, ver, por todos, LEITE, Fábio Carvalho. Estado e religião: liberdade religiosa no Brasil. Curitiba: Juruá, 2014, especialmente p. 76-85; e p. 339-431. 
autodeterminação da pessoa dotada de autonomia efetiva e sensibilidade, que pondera os custos e benefícios de suas decisões?

Um dos caminhos que podem trazer maior segurança para o intérprete é a teria tríplice da autonomia existencial, pela qual a análise dos efeitos que o ato de autonomia produz sobre esferas jurídicas alheias a do seu titular é capaz de delimitar com maior precisão a legitimidade ou não das intervenções paternalistas, ou seja, se elas serão aceitáveis ou se devem ser refutadas em nome da proteção à liberdade pessoal.

\section{TEORIA TRÍPLICE DA AUTONOMIA EXISTENCIAL E LIMITES AO DIREITO DE NÃO SABER}

Em breves linhas, é possível afirmar que a autonomia existencial é espécie do gênero autonomia privada e se configura como instrumento da liberdade individual para realização das potencialidades da pessoa humana e de seus interesses não patrimoniais, incidindo nas situaçôes jurídicas subjetivas situadas na esfera extrapatrimonial, cujo referencial objetivo é o próprio titular no espaço de livre desenvolvimento da personalidade ${ }^{44}$.

$\mathrm{Na}$ legalidade constitucional, o ponto de partida, a premissa inafastável para qualquer investigação sobre a realização dos interesses existenciais deve ser a liberdade para escolher os rumos da própria vida. Todavia, como qualquer outro ato de liberdade, a autonomia existencial pode sofrer limitaçôes ${ }^{45}$, no entanto elas só devem incidir excepcionalmente e apenas quando presentes requisitos que comprovem concretamente a necessidade de tal restrição.

Por tal razão, a autonomia existencial só admite limites externos e não se volta à realização de interesses alheios aos do seu titular, daí porque não se pode sustentar o argumento de que o direito de não saber sucumbiria diante do imperativo de saúde pública. Efetivamente, a prevenção de doenças cuja contaminação pode se dar também por meio de relaçôes sexuais constitui dever pessoal de cada um que

44 Tais considerações foram apresentadas em VIVEIROS DE CASTRO, Thamis Dalsenter. Thamis Dalsenter. A função da cláusula de bons costumes no Direito Civil e a teoria tríplice da autonomia privada existencial. Revista Brasileira de Direito Civil - RBDCilvil, Belo Horizonte, v. 14, p. 99-125, out./dez. 2017.

45 Como esclarece Stefano Rodotà, "A livre construção da personalidade é fórmula que não implica a definição de uma área reservada às escolhas individuais privada de qualquer relação com a regra jurídica. Implica na verdade um instrumento que torna possível a busca autônoma por uma política de identidade pessoal." Rodotà, Stefano. La vita e le regole. Tra diritto e non diritto. Milano: Feltrinelli, p. 22. 
participe do ato sexual. Não se pode assumir como alheia a tarefa de cuidar de si, que, aliás, se impõe independentemente do conhecimento sobre qualquer quadro de doenças.

Tendo em vista a concepção que toma a autonomia existencial como instrumento de emancipação pessoal, não se pode olvidar que a construção da identidade e do projeto de livre desenvolvimento da personalidade demandam espaços democráticos para a realização de experiências intersubjetivas. Daí a necessidade de se estabelecer, sob o prisma das esferas jurídicas que sofrem a incidência de efeitos decorrentes da realização de interesses existenciais, uma nova tipologia das situaçôes jurídicas subjetivas existenciais, com base na eficácia, ou seja, uma categorização que tem como norte o alcance dos efeitos gerados pelo ato de autonomia.

Trata-se, com efeito, de formulação denominada teoria tríplice da autonomia privada existencial ${ }^{46}$ que, através de uma classificação que divide os atos de autonomia em três categorias distintas a depender dos efeitos produzidos e das esferas jurídicas por eles afetadas, permite ao intérprete do direito verificar a necessidade e a legitimidade de intervençóes restritivas feitas pela lei ou aplicadas pelo julgador sobre o exercício da autonomia no caso concreto.

Em decorrência da aplicação desta teoria, os atos de autonomia serão classificados em: (I) atos de eficácia pessoal; (II) atos de eficácia interpessoal; e (III) atos de eficácia social.

Os atos de autonomia de eficácia pessoal são aqueles decorrentes do exercício de situação subjetiva cuja realização de interesses existenciais implica consequências relevantes unicamente para a esfera jurídica do seu titular. Trata-se de situação que não produz efeitos jurídicos diretos e imediatos que acarretem lesão ou ameaça de lesão a esferas jurídicas de terceiros, não admitindo a incidência de elementos limitadores da autonomia. Tome-se como exemplo desse tipo de situação os atos de modificação corporal como a tatuagem, cuja repercussão jurídica se encerra na esfera do titular, ainda que tal ato possa gerar reflexos e impactos culturais para a coletividade.

Com a entrada em Estatuto da Pessoa com Deficiência, é preciso sublinhar, entretanto, que os atos de autonomia de eficácia pessoal poderão ser excepcionalmente limitados quando se tratar de pessoa com deficiência que apresente grau acentuado de vulnerabilidade, desde que as restrições estejam comprovadamente voltadas para o fortalecimento da emancipação pessoal dos sujeitos tutelados pelo

46 Teoria formulada em VIVEIROS DE CASTRO, Thamis Dalsenter. Bons costumes no direito civil brasileiro. São Paulo: Almedina, 2017. 
EPD, tendo em vista que o regime das incapacidades foi profundamente alterado pela Lei n. 13.146/2015.

Os atos de autonomia de eficácia interpessoal são consequência do exercício de situação subjetiva que gera repercussão em esferas jurídicas distintas do titular da situação, alcançando pessoas que não praticaram o ato de autonomia. Essas pessoas precisam ser individualmente identificadas e devem comprovar a situação de serem afetadas pelos efeitos diretos e imediatos do ato de autonomia que causaram lesão ou que apresentam risco real de lesão a seus direitos. Trata-se, portanto, de situação que gera concreto conflito entre a realização de interesses existenciais em esferas jurídicas distintas. Nessas situações, torna-se possível aplicar restrições concretas aos atos de autonomia existencial. O abuso do poder familiar, pelo qual um dos pais pratica alienação parental é um exemplo típico de eficácia interpessoal, na qual o exercício da autonomia familiar acarreta repercussōes para a esfera jurídica alheia, aqui especificamente a do outro genitor e a da criança envolvida.

Nos atos de autonomia de eficácia social a realização de interesses existenciais decorre do exercício de situação subjetiva que apresenta efeitos jurídicos diretos e imediatos que geram ou podem gerar lesão a direitos de um número indeterminado de pessoas. Trata-se de consequências que oferecem risco real de ofensa a direitos de pessoas não necessariamente identificadas ou que causam efetivamente dano a essas pessoas. Nesses casos, diante das repercussões jurídicas negativas para a coletividade, é preciso considerar a necessidade de limitar, também em abstrato, a autonomia existencial do titular para garantia de direitos fundamentais que podem ser lesionados pelo exercício de um interesse individual, o que pode ser feito diretamente no caso concreto através da ponderação ou por meio de lei específica que pró́ba condutas que possam ser classificadas como de eficácia social. Exemplo desse raciocínio é a vedação que o ordenamento brasileiro apresenta à comercialização de partes do corpo, cujo resultado, se fosse lícito, poderia gerar consequências negativas para os sujeitos em situação de miserabilidade que comercializassem seus órgãos, além de acarretar lesão à coletividade, já que a criação de um mercado dessa natureza acabaria com o sistema fraterno de doação de órgãos, que é atualmente pautado pelo princípio da solidariedade social. Também se inclui nessa categoria a impossibilidade de fumar em lugares fechados, tendo em vista as consequências do uso do tabaco para as pessoas, em número impossível de determinar, que terão contato passivo com as substâncias nocivas derivadas do cigarro.

Essa classificação é feita considerando apenas os efeitos diretos e imediatos do ato de autonomia, ou seja, toma por base as consequências que tiveram como causa geradora direta e imediata o exercício da autonomia extrapatrimonial. Ficam afastados os reflexos indiretos ou mediatos que todo ato de autonomia pode produ- 
zir, mas que não possuem o condão de influir na esfera jurídica alheia, pelo que não modificam, extinguem ou constituem o campo de titularidade de outros sujeitos. Qualquer ato jurídico praticado por uma ou por diversas pessoas produzirá repercussões - efeitos - na sociedade, mas nem por isso deve-se considerar que tais reflexos produzidos suscitem a tutela proibitiva do ordenamento jurídico.

Pode-se falar em tais efeitos como ofensa a padróes sociais, hábitos e costumes tradicionalmente observados em determinadas sociedades, o que não é, por si só, problemático do ponto de vista jurídico, de modo que determinada conduta que cause ofensa a certos padrões sociais não acarreta, necessariamente, consequências jurídicas limitadoras da autonomia existencial. Em outros termos, a ofensa a padrões morais não é por si, portanto, razão que atraia a providência jurídica de intervenção limitadora da autonomia privada, eis que não há, em tais casos, ofensa a direitos alheios aos do titular da situação jurídica subjetiva. Em breve síntese, qualquer repercussão reflexa deve ser tolerada por quem as sente, já que não configuram lesão ou ameaça concreta de lesão a direito alheio.

Mas qual será o fundamento para sustentar que as ofensas a padrões morais devem ser toleradas? Sob qual argumento se justifica que tais reflexos indiretos gerados pelos atos de autonomia não estão cobertos pela tutela jurídica do ordenamento brasileiro? Essas ofensas devem ser suportadas por quem as sofre, porque as múltiplas visões de mundo são juridicamente protegidas ou, ao contrário, são suportadas porque determinadas visões de mundo não merecem proteção do direito? Não faltam situações concretas para ilustrar como os valores morais podem se contrapor numa mesma sociedade e suscitar importantes debates acalorados de ordem moral. Alguns exemplos relatados a seguir podem ajudar a compreender esses questionamentos, além de demonstrar de forma mais prática como a teoria sobre os efeitos do ato de autonomia pode ser aplicada concretamente.

Em 2017 duas exposiçôes artísticas protagonizaram polêmicas envolvendo ofensa a padrões sociais. A primeira delas se deu no Museu de Arte Moderna (MAM) de São Paulo, por ocasião da performance realizada na abertura do $35^{\circ}$ Panorama de Arte Brasileira. A performance "La Bête", realizada pelo coreógrafo carioca Wagner Schwartz, é uma leitura interpretativa da obra "Bicho", de Lygia Clark, artista que se consagrou pela criatividade de suas proposiçóes interativas. $\mathrm{O}$ MAM foi alvo de acusações de incitação à pedofilia sustentada por movimentos conservadores após o compartilhamento de fotos e vídeos nos quais uma criança, acompanhada de sua mãe, pode ser vista tocando os pés e a canela do coreógrafo ${ }^{47}$.

47 Dados disponíveis em: http://www.huffpostbrasil.com/2017/09/29/a-questao-da-nudez-na-arte-e-universal-diz-curador-do-mam-sobre-polemica_a_23227725/. Acesso: 30.10.2017. 
Após a repercussão negativa dos fatos, o que gerou uma intensa onda de ataques à liberdade de expressão e à autonomia das famílias que levavam seus filhos para a performance interativa, o debate sobre o tema ganhou espaço nas redes sociais, onde se proliferaram discursos contra e a favor da exposição, com argumentos que poderiam ser resumidos no combate defesa da moral versus defesa da liberdade.

Pouco antes do evento no MAM, a exposição QueerMuseu teve o fechamento antecipado em Porto Alegre após protestos contra o Santander Cultural, que recebeu a mostra, com a justificativa de que os trabalhos expostos promoviam a pedofilia e a zoofilia. Ambas as acusações não produziram eco no Ministério Público e o promotor de Justiça da Infância e da Juventude de Porto Alegre, Júlio Almeida, recomendou a reabertura imediata da exposição. Diante dos rumores que indicavam a chegada da exposição à cidade do Rio de Janeiro, o então prefeito, Marcelo Crivella, se manifestou contra a vinda da mostra, e foi acompanhado pela Assembleia Legislativa do Estado do Rio de Janeiro, a Alerj, onde quarenta deputados assinaram "nota de repúdio e indignação" à possibilidade de ter a QueerMuseu no MAR, Museu de Arte do Rio. Diante da polêmica e das colocações da prefeitura, o Conselho que administra o espaço do museu cancelou as negociações para receber a exposição. ${ }^{48}$

Nos casos apresentados, o exercício da autonomia artística não gerou lesão ou ameaça de lesão a terceiros concretamente identificados ou a um número indeterminado de pessoas. Até mesmo a presença de uma criança na exposição não é fato que atraia necessariamente uma limitação à liberdade, vez que deveres básicos de cuidado e informação indicativa por parte dos Museus e o respeito ao exercício da autoridade parental são suficientes para afastar o risco de lesão e tornar desnecessária e arbitrária qualquer medida restritiva contra as expressões artísticas. $\mathrm{O}$ mesmo raciocínio se aplica ao caso que incrementou o debate sobre o direito de não saber, tendo em vista que os deveres básicos de cautela são capazes de afastar eventuais e futuros efeitos lesivos. Trata-se, com efeito, de mero receio de lesão - que não pode servir de argumento para limitação do direito à privacidade.

Totalmente diferente é o caso de risco real ou potencial de lesão, fundado em circunstâncias não afastáveis a partir de deveres básicos de cautela, e que por isso demandam providências efetivas por parte do ordenamento jurídico. Exemplo desse raciocínio é o caso do casal de duas mulheres americanas surdas desde o nascimento, Sandra Duchesneau e Candy McCullough. Com intuito de gerar um bebê

48 Informaçôes disponíveis em: http://wwwl.folha.uol.com.br/ilustrada/2017/10/1924045-museu-de-arte-do-rio-nao-vai-receber-queermuseu-por-pedido-do-prefeito.shtml. Acesso em: 30.10.2017 
que também sofresse de surdez, o casal decidiu buscar nos bancos de sêmen material genético de homem que também fosse surdo, a fim de aumentar as probabilidades de um filho com os mesmos problemas auditivos que elas tinham. A busca terminou sem sucesso, e elas tiveram que recorrer a um amigo cuja surdez estava presente em muitos de seus familiares. Esse mesmo amigo já havia doado sêmen antes, para fertilização anterior da qual nasceu a primeira filha do casal, Jennifer, que, com cinco anos, só se comunica por meio de sinais. Da segunda fertilização nasceu o bebê, Gauvin McCullough, que também apresentou deficiência auditiva, conseguindo escutar muito pouco apenas por um ouvido. Questionadas sobre a polêmica decisão, o casal afirmou que o filho poderá escolher se quer ou não melhorar mecanicamente a audição por meio de aparelhos. ${ }^{49}$

O casal faz parte de um movimento que se opóe à ideia de surdez como deficiência. De acordo com essa perspectiva, a surdez seria uma identidade cultural. ${ }^{50}$ No entanto, a escolha por bebês surdos suscita mais do que um juízo sobre a conduta ser ética ou não, ou sobre ofensa a padrões morais e culturais. Certamente, a comunidade que reivindica o reconhecimento da cultura dos surdos não vê a questão da eticidade da mesma maneira, o que indica um claro conflito entre diferentes visóes de mundo. Mas os efeitos imediatos dos atos de autonomia dos pais geram consequências jurídicas danosas para os bebês, o que significa que não se trata apenas de ofensa a determinados padrões morais. Tem-se a configuração também de um valor jurídico, o abuso, uma vez que os atos de autonomia dos pais não podem restringir a autonomia existencial dos filhos, em prejuízo destes.

O caso da surdez voluntária de bebês demonstra com clareza a ideia de efeitos imediatos geradores de risco real ou potencial de lesão a direitos de terceiro. Trata-se de risco que pode ser, inclusive, verificado em abstrato, dada a alta probabilidade de surdez diante da escolha de material genético. Tem-se aqui, com efeito, situação de eficácia social, pelo que seria cabível restringir a autonomia familiar e impedir a realização da fertilização em tais condições. A medida mais eficaz em tais casos é a intervenção legislativa. Todavia, na ausência de lei, devem ser aplicadas restrições por meio da intervenção do magistrado no caso concreto.

49 O caso, noticiado pelo site da BBC, no dia 8 de abril de 2002. Disponível em: http://www. bbc.co.uk/portuguese/noticias/2002/020408_surdaro.shtml. Último acesso: 08.06.2017. O relato também pode ser encontrado em BODIN DE MORAES, Maria Celina e KONDER, Carlos Nelson. Dilemas do direito civil-constitucional: casos e decisóes. Rio de Janeiro: Renovar, 2012, p. 47.

50 BODIN DE MORAES, Maria Celina e KONDER, Carlos Nelson. Dilemas do direito civil-constitucional, cit., p. 47. 
Mas qual seria a diferença entre a surdez de bebês por força da escolha do material genético nos casos de fertilização e a surdez de bebês que nasceram de pais surdos, sem qualquer intervenção de técnicas de reprodução assistida? A surdez dos bebês é consequência que ganha relevância jurídica quando é efeito direto e imediato da livre escolha dos pais sobre o material genético, ou seja, a surdez programada é uma alteração na esfera jurídica de terceiros que possibilita a limitação da autonomia diante dos interesses tutelados - não há direito dos pais que possa se opor legitimamente à diminuição permanente da integridade dos filhos. $\mathrm{O}$ mesmo não se pode afirmar sobre os bebês naturalmente surdos, tendo em vista que o risco de filhos de surdos nascerem surdos não se sobrepóe à autonomia dos pais sobre o projeto familiar, tampouco se liga a essa autonomia como consequências diretas e imediatas.

No entanto, a contraposição de valores - de um lado o direito à autonomia das pessoas surdas e de outro a resistência dos que acreditam que a vida digna depende da audição plena - deve ser vista sob outro prisma quando não há interesses de menores envolvidos. Isso porque os argumentos contrários ao desejo dos surdos de não usarem o implante coclear não têm densidade jurídica para limitar a autonomia existencial de sujeitos capazes de discernir. Chega-se à conclusão de que os valores conflitantes não podem limitar a autonomia a partir do raciocínio sobre os efeitos: este ato de autonomia que implica permanência do estado de surdez produz efeitos diretos e imediatos na vida - leia-se esfera jurídica - de terceiros que possam ser concretamente identificados? Há efeitos jurídicos diretos e imediatos que incIdem sobre a coletividade, que permitam afirmar lesão ou risco real de lesão à coletividade e suscitem confronto com interesse público de preservação dos interesses da sociedade?

As duas perguntas têm resposta negativa. Se não há efeitos direitos e imediatos, o que se tem é simplesmente a ofensa a padrões sociais que não constituem, por si, interesses juridicamente tutelados. Diante da ausência de status jurídico dos argumentos que são contrapostos aos direitos dos surdos sobre seus próprios corpos, não há fundamento para limitação da autonomia cujos efeitos que não atingem a terceiros, tampouco à coletividade. Trata-se de exemplo que caracteriza a eficácia pessoal do ato de autonomia. A partir daí, prevalece a noção de que há aqui um espaço de liberdade para a construção do projeto de desenvolvimento pessoal de acordo com a multiplicidade de concepções sobre a vida digna.

É preciso considerar, ainda, que a investigação sobre a irrelevância das ofensas a padrões no plano concreto depende dos resultados da investigação em abstrato: determinados valores compartilhados pela sociedade não poderão figurar como 
valor jurídico, pouco importando se eles são referentes à maioria da população. Não se trata de número de adesões, mas sim de compreender que o recurso aos valores é mecanismo limitado pela moralidade constitucional, pelo que um valor só será enquadrado como valor jurídico se for possível determinar o seu correspectivo axiológico no Texto Constitucional. Não há sentido na investigação dos atos de autonomia de acordo com seus efeitos se aquilo que se contrapõe ao interesse do titular da situação existencial já for, de antemão, impedido de receber a tutela jurídica. A averiguação dos efeitos tem em vista a exclusão de padrões morais que sejam juridicamente irrelevantes, o que pressupõe não ser antijurídico. Ora, sendo assim, parece óbvio que não pode haver dúvidas quanto à impossibilidade de limitar a autonomia por fundamentos contrários ao direito.

No entanto, nada é tão elementar assim quando se trata de analisar quais valores são contrários ao direito, como se vê a partir do famoso caso Richarlyson. Em 2007, o jogador de futebol Richarlyson apresentou queixa-crime contra um cartola do clube Palmeiras, que insinuou que o atleta seria homossexual. Foi negado prosseguimento à ação penal. Dentre os argumentos apresentados pelo juiz, ganharam destaque as afirmações de que "o futebol é jogo viril, varonil, não homossexual", e de que caso o jogador "fosse homossexual, poderia admiti-lo, ou até omitir, ou silenciar a respeito. Nesta hipótese, porém, melhor seria que abandonasse os gramados" $"$ Mas a relevância desse caso de matéria penal está no fato de que os valores que indicam tanto machismo quanto homofobia são compartilhados por grande parte da sociedade. O problema é que mesmo tendo adesão da população, esses valores não encontram respaldo nos valores constitucionais e "não podem funcionar como condição suficiente de juridicidade". ${ }^{2}$

Ganha relevo neste ponto a noção de pluralismo, ${ }^{53}$ pela qual a sociedade é marcada pela diversidade de múltiplas formas, sexual, política, racial. Naturalmente, esta diversidade gera como consequência diferentes visões de mundo, que devem ser asseguradas juridicamente como exercício legítimo da democracia. Como esclarece Luis Roberto Barroso, "o Estado inimigo das minorias, protagonista da repressão e da imposição da moral dominante, como se fosse a única legítima, tem

51 TJSP, 9a V. Crim, proc. n. 936/07, Juiz Manoel Maximiano Junqueira Filho, julg. 5.7.2007.

52 MEDEIROS, Bernardo Abreu de. Positivismo jurídico inclusivo: a possibilidade de incorporação de valores morais ao direito nos estados constitucionais contemporâneos. Dissertação (Mestrado em Direito) Pontifícia Universidade Católica do Rio de Janeiro, Rio de Janeiro, 2009, p. 98.

53 Cf. CITTADINO, Gisele. Pluralismo, direito e justiça distributiva: elementos da filosofia constitucional contemporânea. Rio de Janeiro: Lumen Juris, 2013. 
cedido passo, historicamente, ao Estado solidário, agente da tolerância e da inclusão social." ${ }^{4}$

Assim, as diferentes concepções de vida devem conviver em ambiente marcado pela tolerância, e então a partir do pluralismo torna-se mais fácil sustentar a irrelevância jurídica da ofensa a determinados padrões morais, diante da ausência ou insignificância de seu status jurídico. Trata-se de postura imposta por uma das mais importantes dimensões da dignidade da pessoa humana, que demanda o mesmo reconhecimento para "todos os projetos pessoais e coletivos de vida, quando razoáveis, são dignos de igual respeito e consideração, são merecedores de igual 'reconhecimento". 55

Em síntese, de acordo com a teoria tríplice apresentada, classificação dos atos de autonomia em relação aos efeitos - atos de eficácia pessoal, interpessoal e social - demanda um plano de investigação que deve seguir as seguintes etapas sucessivas:

(i) Verifica-se qual a natureza dos valores contrapostos à autonomia. Deve-se excluir qualquer valor moral que não encontre amparo legal, e que por isso não será considerado jurídico. $\mathrm{Na}$ ausência de valores jurídicos, não há necessidade de prosseguir para a segunda etapa e o ato de autonomia deverá ser classificado como de eficácia pessoal, cujos efeitos jurídicos não extrapolam a esfera jurídica do titular. A eficácia pessoal afasta a incidência de qualquer elemento limitador da autonomia, exceto nos casos regidos pelo Estatuto da Pessoa com Deficiência, como se disse antes. Havendo, por outro lado, valores jurídicos contrapostos à autonomia, passa-se à averiguação dos efeitos;

(ii) Os efeitos diretos e imediatos do ato de autonomia geram lesão ou risco real de lesão à esfera jurídica alheia a do titular da situação? Se a resposta for negativa, trata-se de ato de autonomia de eficácia pessoal e a investigação deve ser encerrada aqui. Se a resposta for afirmativa, passa-se à averiguação do status jurídico da lesão na próxima etapa;

(iii) A lesão que pode ser causada pelo ato de autonomia alcança interesse alheio que goza de status jurídico capaz de limitar os interesses do titular da situação existencial? Se a resposta for negativa, a investigação se encerra aqui,

54 BARROSO, Luís Roberto. Diferente, mas iguais: o reconhecimento jurídico das relações homoafetivas no Brasil. Revista Brasileira de Direito Constitucional-RBDC, n. 17, jan./jun. 2011, p. 112.

55 BARROSO, Luís Roberto. Diferente, mas iguais, cit., p. 127. 
configurando-se o ato de autonomia de eficácia pessoal. Se a resposta for positiva, segue-se para a verificação das esferas jurídicas afetadas;

(iv) As pessoas e suas esferas jurídicas afetadas pelos efeitos do ato de autonomia podem ser concretamente identificadas e individualizadas? Se sim, a investigação é encerrada e resta configurada o ato de autonomia de eficácia interpessoal, que enseja a limitação concreta do ato de autonomia e a ponderação dos interesses contrapostos - o que pressupõe a resolução judicial do conflito. Se a resposta for negativa, prossegue-se para a última etapa da investigação;

(v) $\mathrm{O}$ ato de autonomia existencial causa efeitos diretos e imediatos para um número indefinido de pessoas, gerando lesão ou risco real de lesão para a coletividade? Se foi possível percorrer todas as etapas anteriores e chegar até aqui, respondendo-se afirmativamente à última pergunta formulada, trata-se de ato de autonomia de eficácia social, cuja limitação pode ser feita de maneira mais ampla. Neste tipo de ato, além da restrição da autonomia feita em âmbito judicial, por ocasião do conflito concreto, é possível aplicar outros instrumentos limitadores da autonomia em abstrato, o que pode ser feito também por meio de iniciativa legislativa específica para vedar a conduta.

Todas essas variáveis devem orientar o intérprete na tarefa - quase sempre árdua - de encontrar os fundamentos e os limites legítimos para o exercício da autonomia privada na legalidade constitucional, em seu viés existencial ou patrimonial. A classificação de um ato de autonomia existencial como interpessoal ou social admite a possibilidade de limitação, que pode ser feita em abstrato ou no caso concreto, como se viu antes, o que demanda consideraçôes adicionais sobre qual o instrumento adequado para promover essa restrição à liberdade.

Considerando a aplicação desse raciocínio ao campo do direito de não saber, é preciso sublinhar que o desejo de não saber algo sobre se mesmo, ainda que seja dado verdadeiro sobre situação de saúde como a soropositividade, representa exercício de ato de autonomia que não gera, a priori, efeitos diretos e imediatos para qualquer esfera jurídica alheia a do seu titular. Trata-se de ato de eficácia pessoal, vez que a possibilidade de contágio configura apenas mero receio de ameaça de lesão e não risco real e concreto de lesão, vez que a contaminação pelo vírus HIV pode ser evitada através da adoção de deveres básicos de cautela, que cabem a todas as pessoas que individualmente e não apenas à pessoa soropositiva. Situação diversa seria aquela em que a pessoa ao ser consultada informa não ser soropositivo, 
pois ainda que os deveres de cuidado sejam individuais, tem-se aqui a quebra da confiança e da lealdade que devem ser respeitadas em todas as relaçôes sociais. Daí porque se torna evidente a impropriedade do argumento de interesse público, atrelado à conservação da saúde pública, para limitar a autonomia existencial da pessoa que não deseja conhecer seu dado médico.

Também se torna clara a ilegitimidade do argumento referente ao melhor interesse e ao melhor modelo de vida, que tem como objetivo impor a todos um modelo único de desenvolvimento pessoal. A ideia de um modo de viver é superior ao outro se traduz em intervenção paternalista que não goza de legitimidade, pois afronta gravemente a ideia de democracia pluralista, pelo que se deve proteger e aceitar as múltiplas visões de mundo. Como referido pelo voto vencido, toda pessoa possui o direito de reservar e esconder as próprias fraquezas.

Para além dessas consideraçôes, é preciso reafirmar que a noção de saúde está diretamente ligada à ideia de autonomia corporal, pelo que não se pode impor um único padrão de vida saudável, presumindo que toda e qualquer pessoa se beneficiaria da informação sobre a realidade do seu estado de saúde, aqui precisamente sobre a sua condição de soropositiva. A possibilidade de autodeterminação sobre o próprio corpo pressupõe, obviamente, que qualquer coleta, manipulação, exame, e divulgação de dado biológico somente ocorra mediante autorização expressa da pessoa. O que para uns pode ser a chance adotar precocemente tratamentos médicos para evitar as manifestaçôes da doença, para muitos outros pode representar a ruína dos seus planos de vida, levando, inclusive, à violação de sua saúde mental.

\section{CONSIDERAÇÕES FINAIS}

Os limites para o exercício do direito de não saber só se revelam diante do caso concreto, quando se pode verificar se os efeitos jurídicos diretos e imediatos produzidos pelo exercício da autonomia existencial alcançam esferas jurídicas alheias a do seu titular. Apenas nas hipóteses de atos de eficácia interpessoal e/ou social se admite intervenção na liberdade pessoal para relativizar a tutela do direito de não saber.

Diante da expansão da privacidade e da tutela da autonomia existencial, o intérprete não pode ignorar que o ônus democrático de reforçar proteção da liberdade é fazer com que as pessoas assumam a responsabilidade pessoal pelos seus acertos e pelo resultado negativo de seus erros, lembrando que as decisões estritamente pessoais poderão ser guiadas por razões que a própria razão desconhece. 


\section{REFERÊNCIAS}

ALEMANY, Macario. El paternalismo jurídico, Madrid: Iustel, 2006.

BARROSO, Luís Roberto. Diferente, mas iguais: o reconhecimento jurídico das relações homoafetivas no Brasil. Revista Brasileira de Direito Constitucional - RBDC, n. 17, jan./ jun. 2011.

BOBBIO, Norberto. Da estrutura à função. Trad. Daniela Beccaccia Versiani. Barueri: Manole, 2007.

BOBBIO, Norberto; MATEUCCI, Nicola; PASQUINO, Gianfranco. Dicionário de Política. v. II, Brasília: Editora UnB, 2010.

BODIN DE MORAES, Maria Celina; KONDER, Carlos Nelson. Dilemas do direito civil-constitucional: casos e decisões. Rio de Janeiro: Renovar, 2012.

BODIN DE MORAES, Maria Celina. Na medida da pessoa humana: estudos de direito civil-constitucional. Rio de Janeiro: Renovar, 2010.

BUCAR, Daniel. Controle temporal de dados: o direito ao esquecimento. civilistica.com. Disponível em: <http://civilistica.com/wp-content/uploads/2013/10/Direito-ao-esquecimento-civilistica.com-a.2.n. 3.2012.pdf>. Acesso em: 08/02/2018.

CITTADINO, Gisele. Pluralismo, direito e justiça distributiva: elementos da filosofia constitucional contemporânea. Rio de Janeiro: Lumen Juris, 2013.

DEVLIN, Patrick. The enforcement of morals. Oxford Press University, 1959.

DONEDA, Danilo. Da privacidade à proteção de dados pessoais. Rio de Janeiro: Renovar, 2006.

DWORKIN, Gerald. Paternalism. Monist, LVI, n. 1, junho de 1972.

FRANKENBERG, Günther A gramática da Constituição e do direito. Tradução Elisete Antoniuk. Belo Horizonte: Del Rey, 2007.

LEITE, Fábio Carvalho. Estado e religião: liberdade religiosa no Brasil. Curitiba: Juruá, 2014.

MARTEL, Letícia de Campos Velho. Direitos fundamentais indisponiveis: os limites e os padrões do consentimento para a autolimitação do direito fundamental à vida. Tese de Doutorado. Rio de Janeiro: UERJ.

MEDEIROS, Bernardo Abreu de. Positivismo jurídico inclusivo: a possibilidade de incorporação de valores morais ao direito nos estados constitucionais contemporâneos. Dissertação (Mestrado em Direito) Pontifícia Universidade Católica do Rio de Janeiro, Rio de Janeiro, 2009.

MILL, Stuart. On Liberty. Kitchner: Batoche Books, 2001.

MULHOLLAND, Caitlin. O direito de não saber como decorrência do direito à intimidade. Civilistica.com, n. 1, 2012. Disponível em: <http://civilistica.com/wp-content/ uploads/2012/09/Direito-de-nao-saber-civilistica.com-1.-2012.pdf>. 
•• Direito Civil: Estudos | Coletânea do XV Encontro dos Grupos de Pesquisa - IBDCivil

PALMER, Michael. Problemas morais em medicina. São Paulo: Editora do Centro Universitário São Camilo, 2002.

PERLINGIERI, Perlingieri. O direito civil na legalidade constitucional. Rio de Janeiro: Renovar, 2008.

PERLINGIERI, Pietro. A doutrina do direito civil na legalidade constitucional. In: TEPEDINO, Gustavo (Org.). Direito civil contemporâneo: novos problemas à luz da legalidade constitucional. São Paulo: Atlas, 2008.

RODOTÀ, Stefano. A vida na sociedade de vigilância: a privacidade hoje. A vida na sociedade de vigilância. Rio de Janeiro: Renovar, 2008.

RODOTÀ, Stefano. La vita e le regole. Tra diritto e non diritto. Milano: Feltrinelli.

RODOTÀ, Stefano. Politici, liberateci dalla vostra coscienza. Disponível em: <http://daleggere.wordpress.com/2008/01/13/stefano-rodota-\%C2\%ABpolitici-liberateci-dallavostra-coscienza\%C2\%BB/>. Acesso em: 19 set. 2017.

SANTOS, Juarez Cirino dos. Direito penal - parte geral. Curitiba: ICPC; Lumen Juris, 2005.

SARMENTO, Daniel. Direitos fundamentais e relaçôes privadas. Rio de Janeiro: Renovar, 2008.

SCHRAMM, Fermim. A autonomia difícil. Bioética, Brasília, v. 6, n. 1, p. 27-37, 1998.

SCHREIBER, Anderson. Direitos da personalidade. São Paulo: Atlas, 2011.

SORIANO, Ramón. La desobediencia civil. Barcelona: PPU, 1991.

TEPEDINO, Gustavo. A tutela da personalidade no ordenamento civil-constitucional brasileiro, in Temas de Direito Civil, Rio de Janeiro: Renovar, 2004.

VIVEIROS DE CASTRO, Thamis Dalsenter. A função da cláusula de bons costumes no Direito Civil e a teoria tríplice da autonomia privada existencial. Revista Brasileira de Direito Civil-RBDCilvil, Belo Horizonte, v. 14, p. 99-125, out./dez. 2017.

VIVEIROS DE CASTRO, Thamis Dalsenter. Bons costumes no direito civil brasileiro. São Paulo: Almedina, 2017.

VIVEIROS DE CASTRO, Thamis, ALMEIDA, Vitor. O direito ao esquecimento da pessoa transexual. In: TEPEDINO, Gustavo; TEIXEIRA, Ana Carolina Brochado; ALMEIDA, Vitor (Coord.). Da dogmática à efetividade do direito civil: Anais do Congresso Internacional de Direito Civil Constitucional - IV Congresso do IBDCIVIL. Belo Horizonte: Fórum, 2017.

WARREN, Samuel; BRANDEIS, Louis. The right to privacy. Harvard Law Review. Cambridge: The Harvard Law Review Association, vol. IV, n. 5, dez. 1890. 